\title{
ARTICLE
}

\section{THE EFFECT OF USING WORDLESS PICTURE BOOK ON STUDENTS' ACHIEVEMENT IN WRITING RECOUNT TEXT}

Submitted as Partial Fulfillment of the Requirements for the Degree of Sarjana Pendidikan

By:

SIRIKIT KAROLA BR SEMBIRING

Registration Number: 2113321051

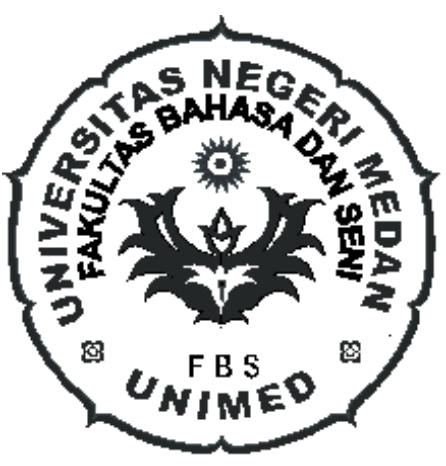

ENGLISH AND LITERATURE DEPARTMENT

FACULTY OF LANGUAGES AND ARTS

STATE UNIVERSITY OF MEDAN

2016 
ARTIKEL

THE EFFECT OF USING WORDLESS PICTURE BOOK ON STUDENTS' ACHIEVEMENT IN WRITING RECOUNT TEXT

Disusun dan Diajukan oleh:

Sirikit Karola Br Sembiring NIM. 2113321051

Telah diverifikasi dan dinyatakan memenuhi syarat untuk diunggah pada jurnal online

Medan, September 2016

Menyetujui

Dosen Pembimbing I

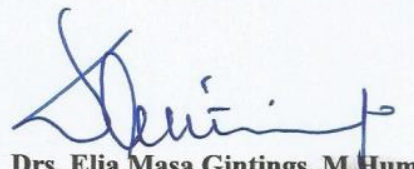

Drs. Elia Masa Gintings, M.Hum.

NIP. 195807071985031007

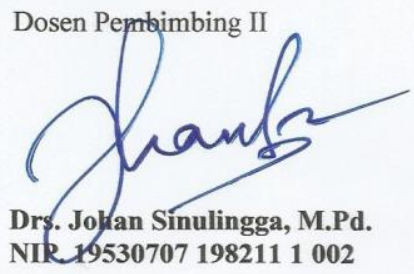

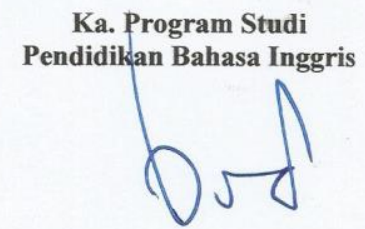

Nora Ronita Dewi, S.Pd., S.S., M.Hum.

NIP. 198005222008122003 


\title{
THE EFFECT OF USING WORDLESS PICTURE BOOK ON STUDENTS' ACHIEVEMENT IN WRITING RECOUNT TEXT
}

\author{
Sirikit Karola Br Sembiring * \\ Elia Masa Gintings** \\ Johan Sinulingga**
}

\begin{abstract}
This study was conducted as an attempt to discover the effect of Using Wordless Picture Book on students' achievement in writing recount text. It was an experimental research. The subject was students of Grade VIII, SMP Negeri 1 Stabat. Two classes from five parallel classes were taken by lottery technique which divided into two groups, 30 students as control group and 30 students as experimental group. The instrument used in this research is to find quantitative data. The analysis in were showed that the scores of the students in the experimental group were significantly higher than the scores of the students in the control group at the level of significant $\mu=0.05$ with the degree of freedom (df) 58 , t-observed value $3.006>t$-table value $>2.000$. The findings indicate that using Wordless Picture Book significantly affected the students' writing achievement. So, English teachers are suggested to use Wordless Picture Book in order to improve students' achievement in writing recount text.
\end{abstract}

Keywords : Wordless Picture Book, Writing Recount Text

* Graduate status

** Lecture Status 


\section{INTRODUCTION}

\section{Background of the study}

English is one of international language and it is learned in a lot of countries. English is used in a particular activity, job and education. In Education of Indonesia, English has became the first foreign language taught at school. It means that English becomes a subject and students are supposed to learn English since the early ages.

In studying English, there are four aspects that will be learned, those are listening, speaking, reading and writing.

Those skills are used to build students' language strategic competence and also to enhance their motivation to learn English. One of the important aspects in studying English is writing.

Writing is an activity of how people put the idea, thought and knowledge on a piece of paper. Writing (as one of the four skills of listening, speaking, reading, writing) has always been formed as part of the syllabus in the teaching English (Harmer, 2004:30).

Indeed, the writing skill is complex and sometimes difficult to teach, requiring mastery not only of grammatical and rhetorical devices but also of conceptual and judgmental elements. Through writing, students are able to express idea, opinion, experience, comment or information in the form of written language.

Heaton (1988: 135) says that writing is the ability which help the writers put their thoughts into words in a meaningful form. The writing skill is complex 
and sometimes difficult to teach, requiring mastery not only of grammatical and rhetorical devices but also of conceptual and judgmental elements.

Based on observation in SMP Negeri 1 Stabat, most of the students always got difficulties when they were asked to write in English., most of the students always got difficulties when they were asked to write in English. It causes of the teacher's teaching media was monotonous and the teachers were not able to create interesting media.

A good way for improving students' writing is by using media. Media is a medium (Plural, media) is a means of communication and source of information. Derived from the latin word meaning "between", the term refers to anything that carries information between a source and a receiver. Examples include video, television, diagrams, printed material, computer programs, and instructor.

According to Fulton (2006: 4) Wordless Picture Book is just what they sound like - books without words (or sometimes with minimal words) that tell a story through pictures. Because they don't rely on words to express their stories, Wordless Picture Book can be used to develop important skills. Wordless Picture Book is a good media for creative writing. By using wordless picture the students will be able to expose their idea in writing. After looking at the picture, students will understand in order to make the story by their own words and will have different story from the other. Thus, the Wordless Picture Book will be useful for students in getting knowledge.

With this condition, the writer interests to investigate the effect of using Wordless Picture Book on students' achievement in writing recount text. 


\section{Research Question}

Related to the background of the study, the research problem is formulated as the following:

“Is the students' achievement taught by using Wordless Picture Book media higher than that taught without Wordless Picture Book in writing a recount text?"

\section{Conceptual Framework}

Writing is important skill besides Speaking, reading and listening. By learning writing, students are trained to be able to express their idea and knowledge to give information in certain situation by using words. Unfortunately, the majority of the students are failed on it. Most of them are unable to write because they lack of vocabularies, interest, and prior knowledge. In reality, many students think that writing is difficult and some of them state that writing is frequently presumed as the most difficult to learn. By responding this problem, the writer tries to find a new media in order to make the students are easy to understand the writing skill, especially on recount text.

In the relation of what mentioned above, the writer will use Wordless Picture Book media on teaching writing in recount text which is assumed as an effective way to be applied to improve writing skill in recount text. This teaching media will be compared to the picture media as well as teaching recount text.

By using Wordless Picture Book media in teaching writing recount text, firstly the teacher will give the pretest to find how the scores that the students achieve before treatment is given. Based on the results, the teacher then divide the 
class into several groups. In each group, there will be mixed between the high, medium and low achiever in the pre-test before. Then the teacher explains the material which is recount text. Then, the teacher shares the Wordless Picture Book for each group and asks them to make a recount story from the Wordless Picture Book story. Each group will make different story because every students have the same opportunity to give their critical thinking. Then, one of them collect all of the ideas from the member of the group and they discuss to arrange those ideas into a good recount text. After the students finished their work, each group tells the story in front of the class, then the teacher give the suggestion for the students' assignment. As the post test, the teacher asks the students to write a recount text individually.

Meanwhile, teaching recount text by using comic, the teacher also will give pretest to know the achievement of the students. Then, give the material about recount text and explain the details about it. The teacher asks the students guess the picture and asking the difficult vocabulary related to the picture, the teacher writes the difficult vocabularies related to the picture on the board, then the students divided into some groups and the teacher share the picture for each group as the example of recount. The teacher asks them to discuss with their partners about the picture and the plot of the story. After finish their work, each group tells the story in front of the class and the teacher give comment and suggestion. At last, the teacher asks the students to make a narrative story individually as the post test. 
Wordless Picture Book is a good way to improve the students' ability in writing recount text. Because, Wordless Picture Book is book that all pages just pictures and no words. So, the students have to expand their imagination and idea to interpret the stories from the pictures. Students are expected to have opportunities to work collaboratively with their friends in the group because the members of the group freely express their own idea without any doubt. Meanwhile, using picture as the media in teaching recount text, the students' is too easy to write the story of recount text, because there are texts on the picture. It makes the students can't explore their idea and imagination. They just arrange a story based on the texts. Picture is usually used to make students interested in reading, so it is not effective way to improve students' ability in writing.

In conclusion, based on the definition above, can be predicted Wordless Picture Book media is effective and optimal to be applied in order to increase students' achievement in writing recount text.

\section{Methodology}

This study is conducted in experimental research design with pre-test and post-test design. The design was applied in order to investigate the effect of using Wordless Picture Book media on students' achievement in writing recount text. This study deals with two groups, namely experimental group and control group. The experimental group taught by using Wordless Picture Book and control group taught without Wordless Picture Book. Both of groups were given pre-test and post-test with the same items. 
There are two variables in this study; they are independent and dependent variable. Independent variable is the effect of using Wordless Picture Book media while the dependent variable is the students' achievement in writing recount text.

Table 1. Research Design

\begin{tabular}{llll}
\hline Group & Pre-test & Treatment & Post-Test \\
\hline Experimental (X) & $\sqrt{ }$ & Using WPB Media & $\sqrt{ }$ \\
Control (Y) & $\sqrt{ }$ & Without wordless picture book & $\sqrt{ }$ \\
& & \\
& & media
\end{tabular}

\section{Population and Sample}

Arikunto (2006:130) states, a population is a set (or collection) of all elements processing one or more attributes of interest.The population of this study was the students of grade Eight of SMP Negeri 1 Stabat. The sample in this research was selected by using lotery technique, 2 classes selected as the sample VIII 3 as the experimental class and VIII 4 class. Each class consists of 30 students.

\section{Technique of Analyzing the Data}

1. In collecting the data, the writing test was given to the students. The students instructed to write a Recount text. In this case, the writer gave a topic. The test was given to both groups experimental and control groups. They were pre-test and post-test. To score the students' performance in writing, some criteria are used. The writer applied the four indicators of Recount writing evaluation. The five indicators are social function, general 
identification, description and language features, mechanics. For all component, students get score 100 points in which the score of.

The t-test formula is used in analyzing the data. The formula is :

$$
t=\frac{\mathrm{Mx}-\mathrm{My}}{\sqrt{\left(\frac{d x^{2}+d y^{2}}{N x+N y-2}\right)\left(\frac{1}{N x}+\frac{1}{N y}\right)}}
$$

In which:

$$
\begin{aligned}
& \text { t } \quad \text { total score } \\
& \mathrm{Mx} \quad \text { : the mean of experimental group } \\
& \mathrm{My} \quad: \text { the mean of control group } \\
& \mathrm{Dx}^{2} \quad: \text { the standard deviation of experimental group } \\
& \mathrm{Dy}^{2} \quad: \text { the standard deviation of control group } \\
& \mathrm{Nx} \quad: \text { the total numbers of experimental group } \\
& \mathrm{Ny} \quad: \text { the total numbers of control group }
\end{aligned}
$$

\section{RESULT AND DISCUSSION}

There were 60 students taken as the sample. The students were divided into two group, experimental group and control group. There were pre-test and post test provided for each group. The result of the test in this research shows that there is difference of the score between both of the group. It can be seen in the table below:

Table 2. The Total Score Pre-Test and Post Test of Experimental Group and Control Group

\begin{tabular}{|l|l|l|l|}
\hline No & The data & Pre-test & Post test \\
\hline
\end{tabular}




\begin{tabular}{|l|l|l|l|l|l|}
\hline & & Experimental & Control & Experimental & Control \\
\hline 1 & Total Score & 1463 & 1270 & 2100 & 1705 \\
\hline 2 & Mean Score & 48.7 & 42.3 & 70 & 56.83 \\
\hline
\end{tabular}

Based on the data above, from the score of experimental group and control group, the mean of pre-test and post test score of experimental group is higher than the mean of pre-test and post test on control group. It shows that the students' score which is taught by Wordless Picture Book is better than the students' score which is taught by using comic.

The result of the test is calculated by using t-test formula. Where:

Table 3. The t-test Formula

\begin{tabular}{|l|l|}
\hline My $=14.07$ & $\mathrm{Mx}=21.23$ \\
\hline $\mathrm{dy}=1872.8$ & $\mathrm{dx}=2895.4$ \\
\hline $\mathrm{Ny}=30$ & $\mathrm{Nx}=30$ \\
\hline
\end{tabular}

After the t-test calculated, it was found that in this study the t-observed is higher than the t-table. It can be seen as follows:

$$
\begin{aligned}
& \text { t-observed }>\text { t-table }(\alpha=0.05) \text { with df }(\mathrm{N}-2) \\
& 3.006>2.000(\alpha=0.05) \text { with df } 58
\end{aligned}
$$

From the result above, it shows that the alternative hypothesis (Ha) is accepted. 
It means that Wordless Picture Book significantly affect students' achievement in writing recount text.

\section{Conclusion and Suggestion}

\section{Conclusion}

From the calculation of the data, it was found that wordless picture book media significantly affect students' achievement in writing recount text. the mean score of students' achievement taught by using Wordless Picture Book as media learning (60) is higher than mean score of students' achievement taught without Wordless Picture Book (56.83). The $t_{\text {observed }}(3.006)$ is higher than $t_{\text {table }}(2.000)$ at the level of significance of 0.05 of two-tailed test. It means that Ha is accepted. Thus, it can be concluded that there is a significant effect of using Wordless Picture Book as Media Learning on Students' Achievement in Writing Recount Text.

\section{Suggestion}

Based on the finding, it is suggested that :

1. For the English teacher, it is better to use Wordless Picture Book in teaching recount writing because by using this media the students can be more enjoyable in writing recount text and hopefully the students' score in writing recount is higher when Wordless Picture Book is used.

2. English teachers should be able to make some variations in teaching writing especially on recount text which is appropriate with the ability of the students so that they can explore their ideas totally. 
3. For students, it will make them easier to make a good recount text and give the students invaluable benefit because it helps them to make writing more fun and make them feel comfort in writing.

4. To all the readers, may this research will bring you into good understanding how to improve the students' recount writing achievement by using Wordless Picture Book. 


\section{REFERENCES}

Arikunto, Suharsimi. 2006 . Prosedur Penelitian : Suatu Pendekatan Praktik. Jakarta : Rineka Cipta.

Best, John. W. 2002. Research in Education. New Delhi : Prentice Hall.

Bloom, B, S. 2006. Taxonomy of Educational Objectives: The Classification of Educational Goals. New York: Longam.

Brown, H. D. 2004. Language Assessment Principles and Classroom Practices. New York : Longman Group.

Daryanto. 2011. Media Pembelajaran. Bandung: Sarana Tutorial Nurani.

Devine, T. G. 1987. Making Sense of Functional Grammar. Sydney : Gerb Stabler.

Ellery, V. 2009. Creating Strategies Readers: Technique for Developing Competency in Phonemic Awareness, Phonics, Fluency, Vocabulary, and Comprehension. New York: International Reading Association Inc.

Fulton, M, Janet. 2006. Talking About Wordless Picture Books. New York.UPS.

Harmer, J. 2003. How to Teach English: An Introduction to the Practice of English Language Teaching. New York: Pearson Education Limited.

Harmer, J. 2004. How to Teach Writing. London: Pearson Education Limited.

Heaton, J.B.1988. Writing English Language Test. New York: addition Longman Group

Hornby. 1995. Definition of Speaking Skill. New York: Publisher.

Harvey, S. A. 2000. Strategies that Work: Teaching Comprehension for Understanding and Engagement. New York: Pembroke Publishers.

Hyland, K. 2002. Teaching and Researching Writing.Britain: Pearson Education.

Hayland, K. 2000. Discriplinary discourses: Social Interactions in Academic Writing. London: Logman.

Kucer, S. C. 2005. Teaching the Dimensions of Literacy. New York: Routledge.

Knapp, P and Watkins, M. 2005. Genre, Text, Grammar.Sydney : University of New South Wales.

Mary, D. A. 2002. Using Wordless Picture Books to Support Emegent Literacy. Human Sciences Press: Early Childhood Education Journal. 
Munadi. 2008. Media Pembelajaran. Jakarta: Gaung Persada Press.

Pardiyono. 2007. Pasti Bisa! Teaching Genre-Based Writing. Yogyakarta. Andi.

Patel, M.F and Jain, M. 2008. English Language Teaching. Jaipur: Sunrise Publisher and Distributors.

Sanggam and Shinoda, K. 2008. Generic Text Structure. Yogyakarta:GrahaIlmu.

http://ARenoldRendra.wordpress.com accessed on May $11^{\text {th }}$

http://Rachmatwahidi.wordpress.com accessed on March $15^{\text {th }}$

http://www.fiveminuteenglish.com/feb28.htm.accessed on February 28. 